\title{
Transposon-mediated mobilization of chromosomally located catabolic operons of the CAM plasmid by TOL plasmid transposon Tn4652 and CAM plasmid transposon Tn3614
}

\author{
Andres A. Mäe† and Ain L. Heinaru \\ Author for correspondence: Andres A. Mäe. Fax: +4618673329.
}

Institute of Molecular and Cell Biology at Tartu University, Estonian Biocentre, Tartu EE2400 Republic of Estonia

\begin{abstract}
The CAM (camphor degradation) plasmid is integrated into the chromosome of Pseudomonas putida PaW-line strains and is not selftransferable as a plasmid via conjugation. Our results show that the mobilization of chromosomally located CAM and the integration of cam-operons into the chromosome of the new Cam+ transconjugants is a recA-independent process mediated by transposons Tn4652 (17 kbp) and Tn3614 (7.2 kbp). Transposon Tn3614 is apparently identical to the left-hand and the right-hand sequences of the TOL plasmid pWWO transposon Tn4654. The insertion of Tn401 inside the left-hand terminal IR of Tn4652 completely inhibited the mobilization of CAM. According to our data transposons Tn4652 and Tn3614 together with CAM plasmid catabolic operons are integrated into the chromosome. We propose that in pseudomonads the transposons Tn4652 and Tn3614 play a key role in the evolution and spread of new catabolic plasmids in nature.
\end{abstract}

Keywords: Pseudomonas, CAM plasmid, TOL plasmid, mobilization, transposon

\section{INTRODUCTION}

Catabolic plasmids in soil pseudomonads are able to mobilize chromosomal genes (Shaham et al., 1973; Chakrabarty \& Gunsalus, 1979) and non-conjugative plasmids (Chakrabarty, 1974; Chakrabarty et al., 1978) at a low frequency (i.e. $10^{-7}$ to $10^{-8}$ ). Such mobilization can be achieved by Mob proteins acting at an oriT site (Derbyshire $e t$ al., 1987) or by the action of a transposon (Sherratt $e t$ al., 1980; Crisona et al., 1980; Simon, 1984; Derbyshire et al., 1987). In the latter case the mobilization of non-conjugative plasmids can be either $\operatorname{rec} A$-dependent (Hooykaas et al., 1982) or rec $A$-independent (BroomeSmith, 1980). In either case, an initial cointegrate structure is resolved by site-specific recombination at res sites to yield the end products of transposition (Kitts et al., 1982).

The TOL plasmid pWW0 provides good examples of recombination events between different DNA regions. This $117 \mathrm{kbp}$ long catabolic plasmid encodes the ability to degrade toluene and related compounds (Williams \& Murray, 1974). The catabolic genes (xylgenes) are located

†Present address: Department of Molecular Genetics, Uppsala Genetic Centre, Swedish University of Agricultural Sciences, PO Box 7010, S-750 07 Uppsala, Sweden. within a $39 \mathrm{kbp}$ segment. Excision of this region from pWW 0 by reciprocal recombination between $1.4 \mathrm{kbp}$ direct repeats leads to the formation of the cryptic plasmid pWW0-8 (Bayley et al., 1977).

Plasmid pWW0 can recombine with R plasmids where the size of the inserts from the TOL plasmid varies from 56 to 104 kbp (White \& Dunn, 1977; Lehrbach et al., 1982). The $56 \mathrm{kbp}$ region, encompassing the $x y l$ genes, and the residual $17 \mathrm{kbp}$ region, formed after deletion of the $39 \mathrm{kbp}$ region, are transposons which have been named Tn4651 and Tn4652, respectively. The structural genes essential for transposition, $\operatorname{tn} p A, \operatorname{tn} p S$ and $\operatorname{tn} p T$, and the resolution site res, are located in the $17 \mathrm{kbp}$ of $\operatorname{Tn} 4652$; there are no transposition functions in the $39 \mathrm{kbp}$ catabolic region which contains the $x y l$ genes (Tsuda \& Iino, 1987). Another large (70 kbp) transposon, Tn 4653 is also present in the TOL plasmid pWW0. This encompasses $\operatorname{Tn} 4651$ and shares with it $\operatorname{tn} p T$, $\operatorname{tn} p S$ and res, and additionally a unique $\operatorname{tn} p A$ (the transposase) and also an adjacent $\operatorname{tn} p \mathrm{R}$ (resolvase) (Tsuda \& Iino, 1988). Both Tn4651 and Tn4653 are class-II transposons (Tn3-like) but, whereas the latter shares similarities with other classII transposons, the former appears to be the first of a new subgroup (Tsuda et al., 1989). Owing to transposition by a Tn3-type transposition mechanism, the TOL plasmid 
Table 1. Bacterial strains and plasmids

Abbreviations: $\mathrm{Mxy}^{+}, \mathrm{Mtol}^{+}, \mathrm{Ben}^{+}, \mathrm{Cam}^{+}$, ability to grow on $m$-xylene, $m$-toluate, benzoate and D-camphor; $\mathrm{Trp}^{-}, \mathrm{Met}^{-}, \mathrm{Ade}^{-}, \mathrm{Leu}^{-}$, $\mathrm{Pro}^{-}, \mathrm{His}^{-}, \mathrm{Ile}^{-}$, requirement for tryptophan, methionine, adenine, leucine, proline, histidine and isoleucine, respectively; $\mathrm{Sm}^{\mathrm{r}}, \mathrm{Cb}^{\mathrm{r}}, \mathrm{Km}^{\mathrm{r}}$, $\mathrm{Tc}^{\mathrm{r}}$, resistance to streptomycin, carbenicillin, kanamycin and tetracycline, respectively; $\operatorname{RecA}^{-}$, mutant of $\operatorname{rec} A$ gene.

\begin{tabular}{|c|c|c|c|}
\hline Strain & Plasmid & Notes & Reference/source \\
\hline \multicolumn{4}{|l|}{ P. putida } \\
\hline $\mathrm{PaW} 1$ & pWW0 & $\mathrm{Mxy}^{+} \mathrm{Mtol}^{+} \mathrm{Ben}^{+} \mathrm{Cam}^{-}$ & Williams \& Murray (1974) \\
\hline PpG1 & CAM & $\mathrm{Mxy}^{-} \mathrm{Mtol}^{-} \mathrm{Ben}^{+} \mathrm{Cam}^{+}$ & Rheinwald et al. (1973) \\
\hline \multirow[t]{6}{*}{ PaW8 } & pWW0-8 & $\mathrm{Mxy}^{-} \mathrm{Mtol}^{-} \mathrm{Ben}^{+} \mathrm{Cam}^{-}$produced by growth on benzoate & Williams \& Murray (1974) \\
\hline & pEST3030 & $\begin{array}{l}\mathrm{Mxy}^{-} \mathrm{Mtol}^{-} \mathrm{Ben}^{+} \mathrm{Cb}^{+} \mathrm{Tn} 401 \text { in HindIIIG/EcoRI-C fragment of } \\
\text { pWW0-8 }\end{array}$ & This study \\
\hline & pEST3036 & $\begin{array}{l}\mathrm{Mxy}^{-} \mathrm{Mtol}^{-} \mathrm{Ben}^{+} \mathrm{Cam}^{-} \mathrm{Cb}^{\mathrm{r}} \mathrm{Tn} 401 \text { in HindIII-E/EcoRI-I } \\
\text { fragment of } \mathrm{pWW} 0-8\end{array}$ & This study \\
\hline & pEST3051 & $\begin{array}{l}\mathrm{Mxy}^{-} \mathrm{Mtol}^{-} \mathrm{Ben}^{+} \mathrm{Cam}^{-} \mathrm{Tn} 401 \text { in HindIII-f/EcoRI-I fragment of } \\
\mathrm{pWW0-8}\end{array}$ & This study \\
\hline & pEST3065 & $\begin{array}{l}\mathrm{Mxy}^{-} \mathrm{Mtol}^{-} \mathrm{Ben}^{+} \mathrm{Cam}^{-} \mathrm{Cb}^{\mathrm{r}} \mathrm{Tn} 401 \text { in HindIII-f/EcoRI-b } \\
\text { fragment of } \mathrm{pWW0-8}\end{array}$ & This study \\
\hline & pEST3070 & $\begin{array}{l}\mathrm{Mxy}^{-} \mathrm{Mtol}^{-} \mathrm{Ben}^{+} \mathrm{Cam}^{-} \mathrm{Cb}^{\mathrm{r}} \mathrm{Tn} 401 \text { in HindIII-B/EcoR-K } \\
\text { fragment of pWW0-8 }\end{array}$ & This study \\
\hline KT2440 & pKG206 & $2 \cdot 3 \mathrm{kbp} P s t \mathrm{I}$ fragment $(\operatorname{cam} C)$ of CAM in $\mathrm{pKT} 240$ & Koga et al. (1986) \\
\hline $\mathrm{PaW} 85$ & - & $\mathrm{Mxy}^{-} \mathrm{Mtol}^{-} \mathrm{Ben}^{+} \mathrm{Cam}^{-}$ & Bayley et al. (1977) \\
\hline PaW340 & - & $\mathrm{Mxy}^{-} \mathrm{Mtol}^{-} \mathrm{Ben}^{+} \mathrm{Cam}^{-} \mathrm{Trp}^{-} \mathrm{Sm}^{\mathrm{r}}$ & Franklin \& Williams (1980) \\
\hline PpG1400 & - & $\mathrm{Mxy}^{-} \mathrm{Mtol}^{-} \mathrm{Ben}^{+} \mathrm{Cam}^{-} \mathrm{Trp}^{-} \mathrm{RecA}^{-}$ & Bagdasarian \& Timmis (1982) \\
\hline PpG1400 & CAM & $\begin{array}{l}\mathrm{Mxy}^{-} \mathrm{Mtol}^{-} \mathrm{Ben}^{+} \mathrm{Cam}^{+} \mathrm{Trp}^{-} \mathrm{RecA}^{-} \text {transconjugant from the } \\
\text { mating AC793CAM } \times \mathrm{PpG} 1400\end{array}$ & This study \\
\hline $\mathrm{AC7} 93$ & CAM & $\mathrm{Mxy}^{-} \mathrm{Mtol}^{-} \mathrm{Ben}^{+} \mathrm{Cam}^{+} \mathrm{Met}^{-}$ & $\begin{array}{l}\text { Gift of P. M. A. Broda } \\
\text { (UMIST, Manchester, UK) }\end{array}$ \\
\hline AC793 & CAM, pEST3617 & $\begin{array}{l}\mathrm{Mxy}^{-} \mathrm{Mtol}^{-} \mathrm{Ben}^{+} \mathrm{Cam}^{+} \mathrm{Met}^{-} \mathrm{Cb}^{\mathrm{r}} \mathrm{Km}^{\mathrm{r}} \mathrm{Tc}^{\mathrm{r}} \text { transconjugant from } \\
\text { the mating AC793 } \times \text { PAO 1822, insertion of Tn } 3614 \text { into RP1 }\end{array}$ & This study \\
\hline EST3000 & CAM & $\begin{array}{l}\mathrm{Mxy}^{-} \mathrm{Mtol}^{-} \mathrm{Ben}^{+} \mathrm{Cam}^{+} \mathrm{Trp}^{-} \mathrm{Sm}^{\mathrm{r}} \text { transconjugant from the } \\
\text { mating } \mathrm{AC} 793 \mathrm{CAM} \times \mathrm{PaW} 340\end{array}$ & This study \\
\hline EST3001 & CAM, pWW0-8 & $\begin{array}{l}\mathrm{Mxy}^{+} \mathrm{Mtol}^{+} \mathrm{Ben}^{+} \mathrm{Cam}^{+} \mathrm{Trp}^{-} \mathrm{Sm}^{\mathrm{r}} \text { transconjugant from the } \\
\text { mating PaW1 } 1 \text { EST3000 }\end{array}$ & This study \\
\hline EST3002 & CAM, pEST3012 & $\begin{array}{l}\mathrm{Mxy}^{-} \mathrm{Mtol}^{-} \mathrm{Ben}^{+} \mathrm{Cam}^{+} \text {deleted derivative of EST3002 isolated } \\
\text { after growth on bensoate }\end{array}$ & This study \\
\hline EST3081 & CAM, pEST3614 & $\begin{array}{l}\mathrm{Mxy}^{-} \mathrm{Mtol}^{-} \mathrm{Ben}^{+} \mathrm{Cam}^{+} \mathrm{Trp}^{-} \mathrm{Sm}^{\mathrm{r}} \mathrm{Cb}^{r} \mathrm{Km}^{\mathrm{r}} \mathrm{Tc}^{\mathrm{r}} \text { transconjugant } \\
\text { from the mating EST3001RP1 } \times \mathrm{PaW} 85 \text {, insertion of Tn } 3614 \\
\text { into the RP1 tra2 gene }\end{array}$ & This study \\
\hline \multicolumn{4}{|c|}{ P. aeruginosa } \\
\hline PAO1822 & RP1 & $\mathrm{Ade}^{-} \mathrm{Leu}^{-} \mathrm{Cb}^{\mathrm{r}} \mathrm{Km}^{\mathrm{r}} \mathrm{Tc}^{\mathrm{r}}$ & $\begin{array}{l}\text { Gift of B. Holloway (Monash } \\
\text { Univ., Victoria, Australia) }\end{array}$ \\
\hline \multicolumn{4}{|l|}{ E. coli } \\
\hline GCB & pOX38:: $\operatorname{Tn} 5$ & $\mathrm{Pro}^{-} \mathrm{His}^{-} \mathrm{Km}^{r} \mathrm{Sm}^{r}$ & $\begin{array}{l}\text { Gift of L. I. Glatman (Gamaleya } \\
\text { Institute, Moscow, Russia) }\end{array}$ \\
\hline
\end{tabular}

pWW0 transposons can be used for the mobilization of non-conjugative plasmids.

We discovered that the CAM (which encodes cam genes necessary for degradation of camphor) plasmid locates in the chromosomes of $\mathrm{PaW}$-line strain of $P$. putida and that $\mathrm{Cam}^{+}$character is easily transferable to isogenic strains with the aid of conjugative plasmids like pWW0-8 (Mäe $e t$ al., 1991). However, because the mobilization efficiency of the TOL plasmid pWW0 is at least a hundred times lower

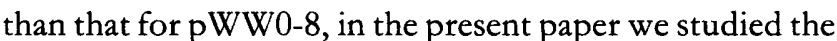
role of TOL plasmid transposons in mobilization of the CAM plasmid.

\section{METHODS}

Bacterial strains and plasmids. The bacterial strains and plasmids used or constructed in this study are described in Table 1.

Media and culture conditions. Luria broth (LB) was used as 
the complete medium and basal salt medium based on M9 salt solution (Maniatis et al., 1982) supplemented with trace elements (Bauchop \& Elsden, 1960) was used as the minimal medium (MS). The final concentrations of antibiotics added to the media were: ampicillin (Ap), $30 \mu \mathrm{g} \mathrm{ml}^{-1}$; carbenicillin $(\mathrm{Cb}), 1000 \mu \mathrm{g}$ $\mathrm{ml}^{-1}$; kanamycin $(\mathrm{Km}), 25 \mu \mathrm{g} \mathrm{ml}^{-1}$; streptomycin (Sm), $1000 \mu \mathrm{g} \mathrm{ml}^{-1}$; and tetracycline (Tc), $12.5 \mu \mathrm{g} \mathrm{ml}^{-1}$. $m$-Toluate was added to $\mathrm{MS}$ at a final concentration of $5 \mathrm{mM}$ and glucose was added to a final concentration of $10 \mathrm{mM}$. D-Camphor was added as a solid in the lid of the Petri dish. Pseudomonas strains were incubated at $30^{\circ} \mathrm{C}$ and Escherichia coli strains at $37^{\circ} \mathrm{C}$.

DNA transformation. The transformation of $P$. putida cells with plasmid DNA was as described by Bagdasarian \& Timmis (1982) and the transformation of E. coli cells was as described by Hanahan (1983).

Mating experiments. Conjugation experiments were carried out in LB as described by Ougham et al. (1983). Transconjugants were detected by growth on $m$-toluate and D-camphor plates. Transfer frequencies were calculated as the ratio of transconjugants to donor cells.

Transposon insertions into plasmids. The source of transposon Tn401 $\left(\mathrm{Cb}^{\mathrm{r}}\right.$ ) was plasmid RP1 (IncP1) in strain $P$. aeruginosa PAO1822(RP1). RP1 was transferred via conjugation into pWW0-8 or pEST3012 containing strains. The resulting transconjugants were selected on plates containing carbenicillin and used as donor strains for subsequent matings with isogenic plasmid free $\mathrm{PaW}$ strains. The source of transposon $\operatorname{Tn} 5\left(\mathrm{Km}^{\mathrm{r}}\right)$ was E. coli mini-F plasmid pOX38:: $\operatorname{Tn} 5\left(\mathrm{Km}^{\mathrm{r}}\right)$, which does not replicate in $P$. putida. pOX $38:: \operatorname{Tn} 5$ DNA was transformed to EST3002 (pEST3012) $\mathrm{Cam}^{+}$and $\mathrm{Cam}^{+} \mathrm{Km}^{\mathrm{r}}$ transformants were used as donor strains for the conjugal transfer of $\mathrm{Cam}^{+}$and $\mathrm{Km}^{r}$ to other host strains.

DNA isolation, analysis and manipulations. Plasmid DNA was isolated by the procedure of Hansen \& Olsen (1978) and Connors \& Barnsley (1982). DNA cleavage by restriction fragments from low melting point agarose gels and agarose gel electrophoresis were performed as described by Maniatis $e t$ al. (1982). The sizes of DNA fragments in agarose gels were calculated by comparing their mobilities with restriction fragments (HindIII, EcoRI) of pWW0 (Downing \& Broda, 1979).

Southern blotting and hybridization. DNA fragments were separated in $1.0 \%$ agarose gels and transferred to nitrocellulose filters according to Southern (1975). DNA probes were labelled to a specific activity of $1-3 \times 10^{7}$ c.p.m. ( $\mu$ g DNA $)^{-1}$ by nicktranslation (Maniatis et al., 1982).

\section{RESULTS}

\section{Mobilization of CAM with plasmid pWW0-8 and its Tn401 derivatives}

Plasmid DNA was not detected in EST3000 CAM. Thus the hybridization between HindIII digested chromosomal DNA of EST3000 CAM and pKG206 containing the cam $C$ gene was investigated. pKG206 hybridized with $4.7 \mathrm{kbp}$ and $2.6 \mathrm{kbp}$ fragments of HindIII digested DNA (Fig. 1) which are indicative of the cam operon (Koga et al., 1986). The ability to utilize camphor $\left(\mathrm{Cam}^{+}\right)$was transferable via conjugation from EST3000 CAM to other recipient strains at a frequency of less than $10^{-8}$ (Table 2). After transformation of the TOL plasmid pWW0 into EST3000 CAM, the resulting Cam ${ }^{+} \mathrm{Tol}^{+}$ transformants transferred the $\mathrm{Cam}^{+}$character to isogenic $\mathrm{PaW}$ strains at a frequency of $10^{-7}$ to $10^{-8}$ (Table 2). However, $\mathrm{Cam}^{+} \mathrm{Tol}^{+}$transconjugants containing plasmid pWW0-8 (for example EST3001) transferred the Cam ${ }^{+}$ character via conjugation at a higher frequency $\left(10^{-3}\right)$ (Table 2).

Hybridization data (not shown) revealed the presence of the $\operatorname{cam} C$ gene in the chromosomal DNA of the Cam ${ }^{+}$ transconjugants.

To verify the role of the TOL plasmid transposon Tn4652 in the mobilization of CAM, we isolated 42 independent pWW0-8:: Tn401 $\left(\mathrm{Cb}^{\mathrm{r}}\right)$ harbouring strains in which the insertion of Tn 401 was outside the Tra- and Rep-regions of this plasmid. The insertion sites were mapped by restriction analysis and six Tn401 insertions in pWW0-8 (including pEST3030) were located outside the TOL plasmid transposons Tn4652 and Tn4654 in restriction fragments HindIII-G/EcoRI-C (Fig. 2a). These Tn401 inserts did not lower the mobilization frequency of the $\mathrm{Cam}^{+}$character from EST3000 CAM (Table 2).

Fourteen Tn401 inserts in pWW0-8 (including pEST3036) did not mobilize the $\mathrm{Cam}^{+}$character from EST3000 CAM (Table 2). In these cases the insertion was located inside the left-hand terminal IR of Tn4652 in restriction fragments HindIII-E/EcoRI-I (Fig. 1a).

Nineteen of the Tn401 inserts in pWW0-8 mobilized $\mathrm{Cam}^{+}$character from EST3000 CAM at the lower frequency of $10^{-5}$ (Table 2). These Tn401 inserts were either in the restriction fragments HindIII-f/EcoRI-I (as in pEST3051) or in the restriction fragments HindIII-f/ EcoRI-b (as in pEST3065) (Fig. 2a).

The remaining three Tn401 inserts (including pEST3070) were in the EcoRI-K fragment (Fig. 2a) leading to a lower $\mathrm{Cam}^{+}$mobilization frequency from EST3000 CAM (Table 2).

Hybridization of chromosomal DNA to pKG206 showed that all of the $\mathrm{Cam}^{+}$transconjugants arising from the mobilization of $\mathrm{Cam}^{+}$by $\mathrm{pWW0-8}$ or pWW0-8: : Tn401 derivatives had the $\operatorname{cam} C$ gene integrated into the chromosome (results not shown).

\section{Mobilization of CAM with the plasmid pEST3012}

The plasmid pEST3012 is a conjugative helper plasmid which is derived from the CAM plasmid. It does not contain the catabolic operons of CAM but does contain the $17 \mathrm{kbp}$ transposon Tn4652. The plasmid pEST3012 has a molecular size of $86 \mathrm{kbp}$ and its restriction pattern differs from that of $\mathrm{pWW0-8}$. As for $\mathrm{pWW0-8,} \mathrm{pEST3012}$ mobilizes $\mathrm{Cam}^{+}$in $\mathrm{PaW}$ strains at the frequency of $10^{-3}$. Ten Tn401 $\left(\mathrm{Cb}^{\mathrm{r}}\right)$ insertion mutations of pEST3012 and 


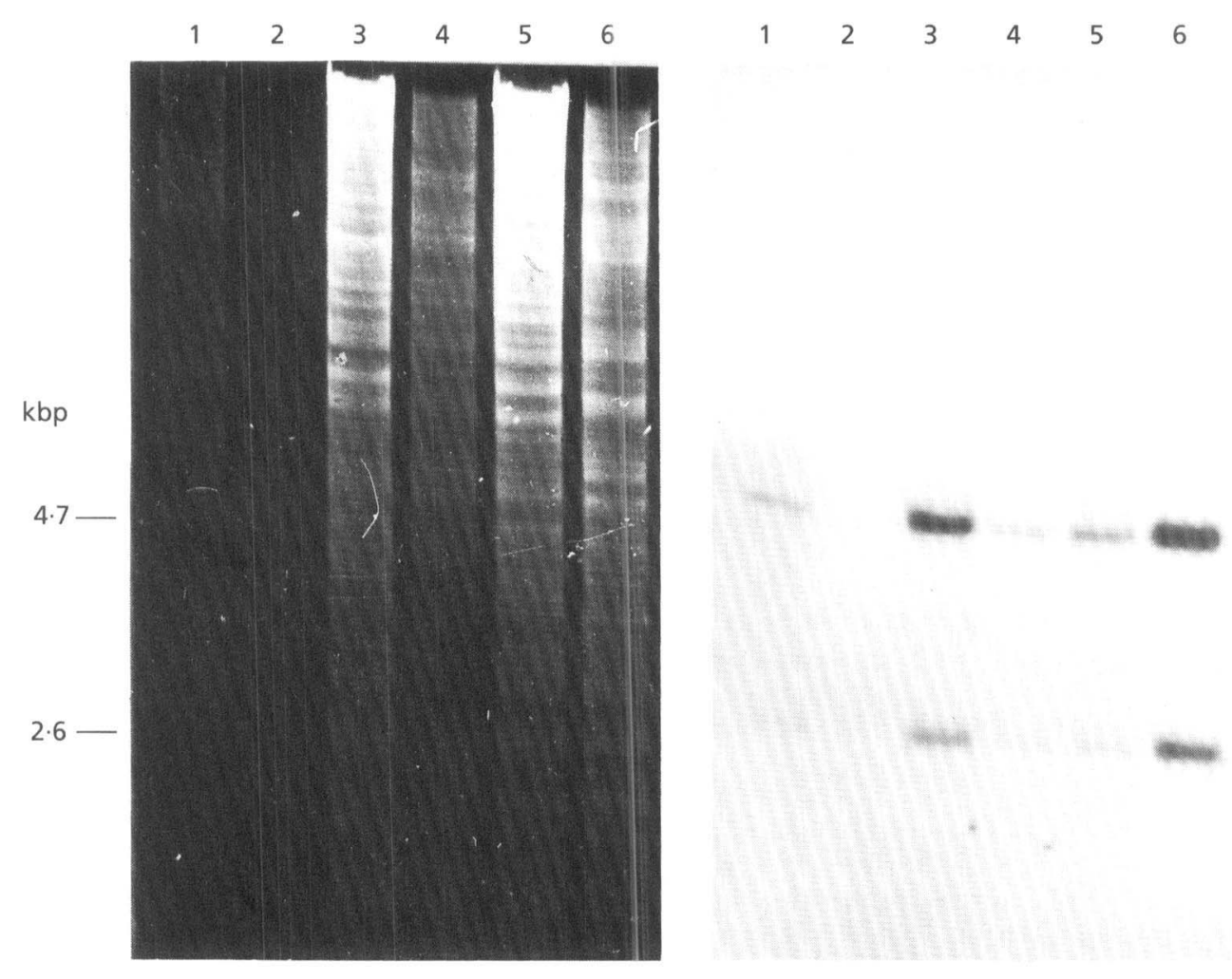

Fig. 1. Agarose gel electrophoresis of genomic DNA restriction fragments (left panel) and the corresponding Southern blot hybridization (right panel). Hybridization analysis of various genomic digests using pK206 (camC) as the labelled probe. Lane 1, P. putida PpG1 (HindIII); lane 2, P. putida PaW340 (HindIII); lane 3, P. putida AC793 (HindIII); lane 4, P. putida PpG1400 CAM (HindIII); lane 5, P. putida EST3001 (HindIII); lane 6, P. putida EST3000 (HindIII).

Table 2. Conjugal mobilization of $\mathrm{Cam}^{+}$character from EST3000 CAM with plasmids pWW0-8::Tn401 (Cb') to P. putida PaW85

\begin{tabular}{|llc|}
\hline $\begin{array}{l}\text { Non-conjugative } \\
\text { catabolic plasmid }\end{array}$ & $\begin{array}{c}\text { Helper } \\
\text { plasmid }\end{array}$ & $\begin{array}{c}\text { Transfer } \\
\text { frequencies of } \\
\text { Cam }{ }^{+} \text {character } \\
\text { on the selection of } \\
\text { transconjugants } \\
\text { on D-camphor }\end{array}$ \\
\hline CAM & - & $\leqslant 10^{-8}$ \\
CAM & pWW0 & $10^{-7}-10^{-8}$ \\
CAM & pWW0-8 & $10^{-3}$ \\
CAM & RP1 & $<10^{-8}$ \\
CAM & pEST3030 & $1 \cdot 0 \times 10^{-3}$ \\
CAM & pEST3036 & $<10^{-8}$ \\
CAM & pEST3051 & $1.3 \times 10^{-5}$ \\
CAM & pEST3065 & $1.0 \times 10^{-5}$ \\
CAM & pEST3070 & $0.6 \times 10^{-8}$ \\
\hline
\end{tabular}

five $\operatorname{Tn} 5\left(\mathrm{Km}^{\mathrm{r}}\right)$ insertion mutations of pEST3012 were selected. All of the $\operatorname{Tn} 401$ and $\operatorname{Tn} 5$ insertions were located in a $7.0 \mathrm{kbp}$ region in pEST3012 at the left-hand side of
Tn4652 (Fig. 2a). Transformation of ten pEST3012:: Tn401 and five pEST3012::Tn5 derivatives into EST3000 CAM resulted in mobilization of $\mathrm{Cam}^{+}$at a frequency of between $10^{-3}$ to $10^{-4}$; this is comparable to the frequencies mediated by the helper plasmids pWW0-8 and pWW0-8:: Tn401.

\section{Mobilization of CAM with RP1::Tn3614}

Four EcoRI fragments of AC793 CAM chromosomal DNA gave strong hybridization with pWW0-8 DNA (data not shown). Three fragments were the same size as EcoRI fragments W, S, Z and the fourth (n) was $2.65 \mathrm{kbp}$ of $N$ and $G$. Because these fragments cover the right-hand and left-hand sequences of Tn4654 in pWW0-8 (Fig. 2a), it was considered to be a putative transposon, $\operatorname{Tn} 3614$. To study the properties of this putative transposon in more detail it was introduced into plasmid RP1 as follows.

Firstly, plasmid RP1 was transferred via conjugation at a frequency of $10^{-4}$ into AC793 CAM. Then 20 independent AC793 CAM RP1 clones were mated individually with the recipient strain $\mathrm{PaW} 340$. One out of a hundred clones tested contained the plasmid RP1 with an insertion of $7 \cdot 2 \mathrm{kbp}$ of DNA. DNA/DNA hybridization and restriction mapping revealed that this $7.2 \mathrm{kbp} \mathrm{CAM} \mathrm{plasmid}$ transposon is apparently identical to EcoRI fragments 
(a) $\underline{0} \quad 10 \mathrm{kbp}$

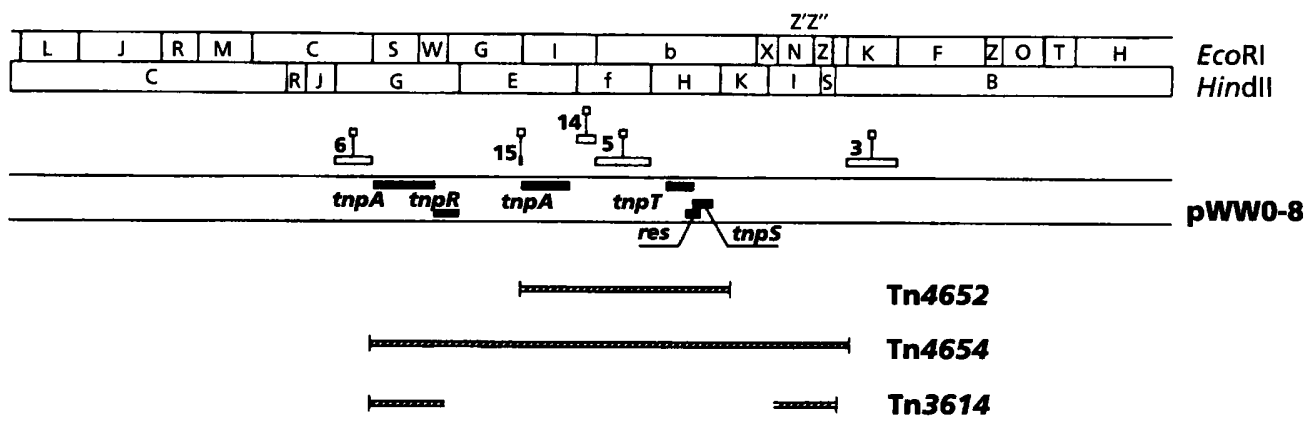

(b)

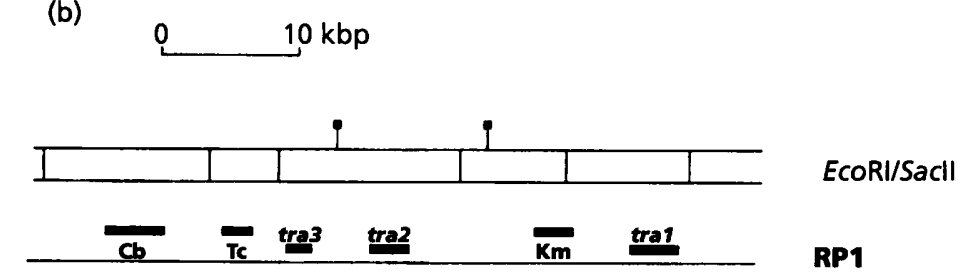

Fig. 2. (a) EcoRI and HindIII cleavage map of pWW0-8 showing the insertion sites for Tn401 ( $\square$ ). The region of Tn401 insertion into pWW0-8 and the number of different clones studied are shown in open boxes. The filled boxes indicate the Tn4652 and Tn4654 genes: tnpA (transposase), tnpR and tnpT,tnpS (resolvase), res (resolution site) (Tsuda \& lino, 1987, 1988). The hatched boxes indicate DNA present in transposons Tn4654, Tn4652 (Tsuda \& lino, 1987, 1988) and Tn3614 (this paper). (b) EcoRI/Sacll cleavage map of RP1 (Nakazawa et al., 1980) showing the insertion sites of Tn3614 in EST3080 (pEST3617) and EST3081 (pEST3614) ( $)$. The filled boxes indicate the transfer genes (tra1, tra2, tra3) and the genes for carbenicillin $(\mathrm{Cb})$, tetracycline $(\mathrm{Tc})$ and kanamycin $(\mathrm{Km})$ resistance.

Table 3. Conjugal mobilization of $\mathrm{Cam}^{+}$character with plasmids RP1::Tn3614

\begin{tabular}{|llc|}
\hline \multicolumn{1}{|c|}{ Mating } & $\begin{array}{c}\text { Transfer } \\
\text { frequencies of } \\
\text { Cam }\end{array}$ \\
& & $\begin{array}{c}+ \text { character } \\
\text { on the selection of } \\
\text { transconjugants } \\
\text { on D-camphor }\end{array}$ \\
& $\times$ PaW85 & $<10^{-8}$ \\
EST300 CAM RP1 & $\times \mathrm{PaW} 340$ & $2.0 \times 10^{-8}$ \\
AC793 CAM RP1 & $\times \mathrm{PaW} 340$ & $1 \cdot 7 \times 10^{-3}$ \\
AC793 CAM pEST3617 & $3.0 \times 10^{-3}$ \\
EST3000 CAM pEST3617 $\times \mathrm{PaW} 85$ & $3.9 \times 10^{-6}$ \\
AC793 CAM pEST3614 & $\times \mathrm{PaW} 340$ & $2.0 \times 10^{-6}$ \\
EST3081 CAM pEST3614 $\times \mathrm{PaW} 340$ & & \\
\hline
\end{tabular}

$\mathrm{W}, \mathrm{S}, \mathrm{Z}, \mathrm{n}$ and locates in RP1 close to the tet genes not interrupting the tra functions of RP1 (Fig. 2b). This derivative of RP1 (pEST3617) mobilized the Cam ${ }^{+}$ character to a frequency of $10^{-3}$. Plasmid RP1 does not mobilize $\mathrm{Cam}^{+}$character at a detectable level (Table 3).

In the second series of experiments EST3001(RP1) was used as a donor in matings with PaW85 and trans- conjugants were selected on D-camphor and kanamycin containing MS media. One out of 257 transconjugants contained a single plasmid, pEST3614, which was larger than RP1, and an insertion of DNA in the tra2 gene of RP1 consistent with transposon $\operatorname{Tn} 3614$ was detected (Fig. 2b). The Cam ${ }^{+}$character was transferred from this strain into the recipient strain $\mathrm{PaW} 85$ at a frequency of $10^{-6}$ (Table 3). These new $\mathrm{Cam}^{+}$transconjugants did not contain pEST3614 but the plasmid RP1 and are not able to mobilize the $\mathrm{Cam}^{+}$character. The difference of $10^{3}$ in $\mathrm{Cam}^{+}$mobilization efficiencies between pEST3617 and pEST3614 is probably due to the frequency of excision of Tn3614 from RP1.

\section{RecA-independent mobilization of CAM with transposons Tn4652 and Tn3614}

The relative efficiencies of transpositional mobilization of CAM by transposons $\operatorname{Tn} 4652$ and $\operatorname{Tn} 3614$ either into rec $A^{-}$strain PpG1400 or from PpG1400 into PaW strains were determined. The three plasmid variants $\mathrm{pEST} 3617$, pEST3012:: Tn401 and pWW0-8::Tn401 (pEST3030) produced similar results both in the $\operatorname{rec} A^{-}$strain PpG1400 CAM and in the $\operatorname{rec} A^{+}$strain AC793 (Table 4). These three plasmids mediated the mobilization of the $\mathrm{Cam}^{+}$ character at a frequency of between $10^{-3}$ and $10^{-4}$ into the new recipients. 
Table 4. Conjugal mobilization of $\mathrm{Cam}^{+}$character in $\operatorname{rec}^{+}$and rec $A^{-}$strains

\begin{tabular}{|c|c|c|c|}
\hline \multirow[t]{2}{*}{ Mating } & & \multicolumn{2}{|c|}{$\begin{array}{l}\text { Transfer frequencies of } \\
\mathrm{Cam}^{+} \text {and } \mathrm{Cb}^{\mathrm{r}} \text { characters } \\
\text { depending on the selection } \\
\text { conditions }\end{array}$} \\
\hline & & $\begin{array}{c}\text { Glucose } \\
+ \\
\text { carbenicillin }\end{array}$ & D-Camphor \\
\hline AC793 CAM & $\times \mathrm{PpG} 1400$ & 0 & $<10^{-8}$ \\
\hline AC793 CAM pEST3617 & $\times$ PpG1400 & $0.5 \times 10^{-4}$ & $2 \cdot 0 \times 10^{-4}$ \\
\hline AC793 CAM pEST3012:: Tn401 & $\times$ PpG1400 & $4.4 \times 10^{-2}$ & $1.8 \times 10^{-2}$ \\
\hline AC793 CAM pEST3030 & $\times$ PpG1400 & $2 \cdot 7 \times 10^{-4}$ & $4.8 \times 10^{-3}$ \\
\hline PpG1400 CAM & $\times$ PaW85 & 0 & $2 \cdot 1 \times 10^{-7}$ \\
\hline PpG1400 CAM pEST3617 & $\times \mathrm{PaW} 85$ & $0.8 \times 10^{-3}$ & $1.4 \times 10^{-2}$ \\
\hline PpG1400 CAM pEST3012:: Tn401 & $\times$ PaW85 & $5 \cdot 7 \times 10^{-3}$ & $1.5 \times 10^{-3}$ \\
\hline PpG1400 pEST3030 & $\times \mathrm{PaW} 85$ & $1.0 \times 10^{-4}$ & $2.6 \times 10^{-4}$ \\
\hline
\end{tabular}

\section{DISCUSSION}

The results presented here show that mobilization of chromosomally located CAM could be achieved by conjugative helper plasmids via the TOL plasmid transposon $\operatorname{Tn} 4652$ and the CAM plasmid transposon $\operatorname{Tn} 3614$. Tn 3614 is not a spontaneous derivative of Tn4654 (Tsuda \& Iino, 1988) from which Tn4652 (Tsuda \& Iino, 1987) has been deleted. The fragments of Tn4654 EcoRI-G, the part of EcoRI-N and the part of RcoRI-X (i.e. DNA from both ends of $\operatorname{Tn} 4652$ ) are not in $\operatorname{Tn} 3614$ (Kivisaar et al., 1988). $\operatorname{Tn} 3614$ is an independent transposon that is present in the derivatives of RP1 or in the chromosome of AC793.

The TOL plasmid transposons $\operatorname{Tn} 4651$ and $\operatorname{Tn} 4653$ are both Tn3-like (class-II) transposons but the former does not share similarities with other class-II transposons and appears to be the first of a new subgroup (Tsuda et al., 1989).

The transposons $\operatorname{Tn} 4651$ and $\operatorname{Tn} 4653$ contain the isofunctional transposase gene $\operatorname{tn} p A$ determining the formation of cointegrates as intermediates of transposition (Tsuda \& Iino, 1988). The dissociation of cointegrates needs three components determined by Tn 4652: the cis active res site and the trans active products of the tnpS and $\operatorname{tn} p \mathrm{R}$ genes.

Comparison of the maps of $\operatorname{Tn} 4651$ and $\operatorname{Tn} 4653$ (Tsuda \& Iino, 1988) with the inserts of pWW0 in the eight $\mathrm{R}:$ : pWW0 cointegrates studied by Lehrbach et al. (1982) revealed that only two correspond to the $56 \mathrm{kbp}$ Tn 4651 , but four to the $69 \mathrm{kbp}$ transposon $\mathrm{Tn} 4653$. One of the remaining two cointegrates shares one terminus common to $\operatorname{Tn} 4651$ and the other with $\operatorname{Tn} 4653$. Although $\operatorname{Tn} 4651$ and $\operatorname{Tn} 4653$ share the same $\operatorname{tn} p$ genes, the majority of recombinational events already described did not explain the transpositions from pWW0 (Assinder \& Williams, 1990) completely.
Transposon mediated mobilization of a chromosomally located CAM plasmid is $\operatorname{rec} A$ independent. Several experimental results lead to this conclusion. First, hybridization of chromosomal and plasmid DNA of $\mathrm{Cam}^{+}$ transconjugants with ${ }^{32} \mathrm{P}$-labelled cloned fragments of Tn4652 and $\operatorname{cam} C$ containing plasmid pKG206 showed that after the mobilization of CAM to the new recipient strain only the conjugative helper plasmid pWW0-8, pEST3012 or RP1::Tn3614 are detectable. Also, the catabolic operons of the CAM plasmid are present in the chromosome (Fig. 1). Secondly, the insertion of transposon Tn401 $\left(\mathrm{Cb}^{\mathrm{r}}\right)$ from plasmid RP1 inside the left-hand terminal IR of Tn4652 inactivates the mobilization of $\mathrm{Cam}^{+}$character (Fig. 2a).

Thirdly, independently isolated pWW0-8:: Tn401 clones in which $\operatorname{Tn} 401$ is located between the $\operatorname{tn} p A$ and tn $p T / \operatorname{tn} p S$ genes of Tn4652 mobilized chromosomal CAM at a frequency of $10^{-5}$ (Table 2, Fig. 2a). This is comparable with the mobilization frequency $\left(10^{-6}\right.$ to $10^{-7}$ ) of CAM by TOL plasmid PWW0 in which catabolic genes of TOL are located in the same region as Tn 4652. However, this is more than a hundred times lower than the frequency achieved with $\mathrm{pWW} 0-8$ or pWW0-8:: Tn401 plasmids in which Tn401 insertion is outside the TOL plasmid transposons (Fig. 2a). A suitable explanation is that this area in Tn4652 is somehow important for the transpositional mobilization of CAM.

Our results explain the mechanism of the mobilization of non-conjugative plasmids by helper plasmids with the formation of unstable cointegrates before conjugal transfer. Cointegrate molecules could not be detected in the samples of plasmid DNA because the linked molecules were up to $300 \mathrm{kbp}$ in size and could not be detected intact. Also, cointegrates probably have a very short life span in the cell.

The fact that $\operatorname{Tn} 4652$ and $\operatorname{Tn} 3614$ are present in different conjugative helper plasmids should facilitate their key 
role in the development and spread of catabolic plasmids in natural bacterial populations.

\section{References}

Assinder, S. J. \& Williams, P. A. (1990). The TOL plasmid: determinants of the catabolism of toluene and the xylenes. $A d v$ Micrab Pbysiol 31, 1-70.

Bagdasarian, M. \& Timmis, K. N. (1982). Host vector systems for gene cloning in Pseudomonas. Curr Top Microbiol Immunol 96, 46-47.

Bauchop, T. \& Elsden, S. R. (1960). The growth of microorganisms in relation to their energy supply. $J$ Gen Microbiol 23, 469-495.

Bayley, S. A., Duggleby, C. J., Worsey, M. J., Williams, P. A., Hardy, K. \& Broda, P. (1977). Two models of loss of the TOL function from Pseudomonas putida mt-2. Mol \& Gen Genet 154, 203-204.

Broome-Smith, J. (1980). RecA independent, site specific recombination between ColEI or ColK and a miniplasmid they complement for mobilization and relaxation: for the mechanism of DN A transfer during mobilization. Plasmid 4, 51-63.

Chakrabarty, A. M. (1974). Dissociation of degradative plasmid aggregate in Pseudomonas. J Bacteriol 118, 815-820.

Chakrabarty, A. M. \& Gunsalus, I. C. (1979). Chromosomal mobilization from a rec $A$ mutant of Pseudomonas putida. Mol \& Gen Genet 176, 151-154.

Chakrabarty, A. M., Friello, D. A. \& Bopp, L. (1978). Transposition of plasmid DNA segment specifying hydrocarbon degradation and their expression in various microorganisms. Proc Natl Acad Sci US. A 75, 3109-3112.

Connors, M. A. \& Barnsley, E. A. (1982). Naphthalene plasmids in Pseudomonas. J Bacteriol 154, 1096-1101.

Crisona, N. J., Nowak, J. A., Negaiski, H. \& Clark, A. J. (1980). Transposon mediated conjugational transmission of nonconjugative plasmids. J Bacteriol 142, 701-713.

Derbyshire, K. M., Hartfull, C. \& Willetts, N. (1987). Mobilization of the nonconjugative plasmid RSF1010: a genetic and DNA sequence analysis of the mobilization region. Mol \& Gen Genet 206, 161-168.

Downing, R. G. \& Broda, P. A. (1979). A cleavage map of the TOL plasmid of Pseudomonas putida mt-2. Mol \& Gen Genet 68, 189-191.

Franklin, C. H. \& Williams, P. A. (1980). Construction of a partial diploid for the degradative pathway encoded by the TOL plasmid ( $\mathrm{pW} \mathrm{W}^{\prime} 0$ ) from Pseudomonas putida $\mathrm{mt}-2$ : evidence for the positive nature of the regulation by the $x y / \mathrm{R}$ gene. Mol \& Gen Genet 177, $321-328$.

Hanahan, D. (1983). Studies on transformation of E. coli with plasmids. $J$ Mol Biol 166, 577-580.

Hansen, J. E. \& Olsen, R. H. (1978). Isolation of large bacterial plasmids and characterization of the P2 incompatibility group plasmids pGM1 and pGM5. J Bacteriol 35, 227-238.

Hooykaas, P. S. S., den Dulk-Ras, H. \& Chilperoort, R. A. (1982). Method for transfer of large cryptic, non-selftransmissible plasmids : ex planta transfer of the virulence plasmid of Agrobacterium rbozogenes. Plasmid 8, 94-96.

Kitts, P., Symington, L. \& Burke, M. (1982). Transposon-specific site-specific recombination. Proc Natl Acad Sci US A 79, 46-50.
Kivisaar, M., Nurk, A., Tamm, A., Măe, A., Habicht, J. \& Heinaru, A. (1988). Transposons of the TOL plasmid $\mathrm{pWW} 0$ are involved in transposition and expression of catabolic operons and conjugal mobilization of metabolic plasmids. Recent Adv Biotechnol Appl Biol 173-181.

Koga, H., Yamaguchi, E. \& Aramatiki, H. (1986). Cloning, regulation and nucleotide sequence of the cam hydroxylase operon. Proc Natl Acad Sci US A 83, 883-893.

Lehrbach, P. R., Ward, J., Meulien, P. \& Broda, P. (1982). Physical mapping of TOL plasmid $\mathrm{pWW0}$ and $\mathrm{pND} 2$ and various R-plasmid TOL derivatives from Pseudomonas spp. J Bacteriol 152, 1280-1283.

Maniatis, T., Fritsch, E. F. \& Sambrook, J. (1982). Molecular Cloning. A Laboratory Manual. Cold Spring Harbor, NY: Cold Spring Harbor Laboratory.

Mäe, A. A., Habicht, J. K., Nurk, A. E. \& Heinaru, A. L. (1991). Transposons Tn4652 and Tn3614 of the TOL plasmid pWW0 are involved in conjugal mobilization of chromosomally located catabolic cam operons. Genetika 27, 773-782 (in Russian).

Nakazawa, T., Inouye, S. \& Nakazawa, A. (1980). Physical and functional mapping of RP4-TOL plasmid recombinants : analysis of insertion and deletion mutants. $J$ Bacteriol 144, 222-231.

Ougham, H. J., Taylor, D. G. \& Trudgill, P. W. (1983). Camphor revisited: involvement of a unique monooxygenase in metabolism of 2-oxo-4,5,5-trimethyl-cyclopentanylacetic acid by Pseudomonas putida. J Bacteriol 153, 140-152.

Rheinwald, J. G., Chakrabarty, A. M. \& Gunsalus, I. C. (1973). A transmissible plasmid controlling camphor oxidation in Pseudomonas putida. Proc Natl Acad Sci US A 70, 855-859.

Shaham, M., Chakrabarty, A. M. \& Gunsalus, I. C. (1973). Camphor plasmid mediated chromosomal transfer in Pseudomonas putida. $J$ Bacteriol 116, 9444-9449.

Sherratt, D., Arthur, A. \& Burke, M. (1980). Transposon-specified, site-specific recombination system. Mol \& Gen Genet 176, 275-281.

Simon, R. (1984). High frequency mobilization of Gram-negative bacterial replicons by the in vitro constructs Tn5-Mob transposon. Mol \& Gen Genet 196, 1413-1420.

Southern, E. M. (1975). Deletion of specific sequences among DNA fragments separated by gel electrophoresis. $J \mathrm{Mol}$ Biol 98, 503-517.

Tsuda, M. \& lino, T. (1987). Genetic analysis of a transposon carrying toluene degrading genes on a TOL plasmid $\mathrm{pW}$ W 0 . Mol \& Gen Genet 210, 270-278.

Tsuda, M. \& lino, T. (1988). Identification and characterization of Tn4653, a transposon covering the toluene transposon Tn4651 on TOL plasmid pWW0. Mol \& Gen Genet 213, 72-77.

Tsuda, M., Minegishi, K. J. \& lino, T. (1989). Toluene transposons Tn4651 and Tn4653 are class II transposons. I Bacteriol 171, 1386-1393.

White, G. P. \& Dunn, N. W. (1977). Apparent fusion of the TOL plasmid with the R91 drug resistance plasmid in Pseudomonas aeruginosa. Aust J Biol Sci 30, 345--355.

Williams, P. A. \& Murray, K. (1974). Metabolism of benzoate and the methylbenzoates by Pseudomonas putida (arvilla) $\mathrm{mt}-2$ : evidence for the existence of a TOL plasmid. J Bacteriol 120, 416-423.

Received 22 May 1993; revised 15 August 1993; accepted 26 October 1993. 